模擬火山れきに対する登山用ヘルメットの耐衝撃特性†

\author{
山田 浩之* 鵜飼 悠帆** 樋口 理宏*** 立山 耕平**** \\ 佐々木 寿***** 保科 祐一郎****** 和田野 加恵 $* * * * * *$ 小笠原 永久*
}

\title{
Impact Resistance of Mountaineering Helmets to Simulated Lapilli
}

by

\author{
Hiroyuki Yamada*, Yuho UkaI ${ }^{* *}$, Masahiro Higuchi***, Kohei TateYama**** \\ Hisashi SASAKI ${ }^{* * * * *}$, Yuichiro Hoshina ${ }^{* * * * * *}$, Kae Wadano ${ }^{* * * * * *}$ and Nagahisa OGaSAWARA*
}

\begin{abstract}
In recent years, casualties due to the impacts of falling lapilli and ballistic ejecta resulting from volcanic eruptions with unclear precursors have increased. However, while research and development efforts aimed at protecting people from such scattered ejecta via improved volcanic shelters are progressing, there has been little research on volcanic disaster prevention measures aimed at directly protecting the human body. Accordingly, this study reports on the development of an impact test apparatus and a human head model that can be used to evaluate the impacts of volcanic lapilli as well as the results of our impact resistance evaluation of a commercially available mountaineering helmet (ravina FLUQUE made by Tanizawa Seisakusho, Ltd.). In our experiments, vitrified grindstone with a standard density of approximately $2400 \mathrm{~kg} / \mathrm{m}^{3}$ were used as simulated lapilli and launched at the helmet at velocities of approximately $40-80 \mathrm{~m} / \mathrm{s}$. Impact safety was evaluated from the damage sustained by the helmet and the head injury criterion (HIC) value, which was calculated via a triaxial accelerometer installed on the head model. Experimental results show that the damage to mountaineering helmet used in this study was small and that the HIC value was low even when it was impacted by lapilli equivalents with diameters up to $30 \mathrm{~mm}$ travelling at velocities of up to approximately $60 \mathrm{~m} / \mathrm{s}$, thereby suggesting that the mountaineering helmet provided sufficient protection up to that impact velocity. Additionally, summarizing the relationship between the interior/exterior damage of the helmet and the HIC value, it was found that the HIC values can vary significantly due to deformation and fracture of the protective foam material mounted inside the helmet.
\end{abstract}

\section{Key words}

Impact, Lapilli, Mountaineering helmet, Volcanic eruption, Head injury criterion, Impactresistant design

\section{1 緒言}

日本は, 世界有数の火山大国の一つである. 火山噴火予 知連絡会が定義している「概数過去 1 万年以内に噴火した 火山及び現在活発な噴気活動のある火山」の数は 2021 年 現在で 111 存在している. 日本人は, 古くからこれらの多 くの火山と共存しているが，時に大きな災害を受けるこ とになる. 火山災害の要因となる主な火山現象は, 火山れ きおよび火山岩塊（一般的に噴石と称される）, 火砕流, 融雪型火山泥流, 溶岩流, 火山灰, 火山ガス等が挙げられ る. ${ }^{11,2)}$ これら火山災害による死傷の原因として, 火砕流 や火山泥流が最も高い割合を占める. しかし，近年では，
前兆が不明膫な噴火により飛散する火山れき（直径 2 64 $\mathrm{mm}$ ) や火山岩塊（直径 $64 \mathrm{~mm}$ 以上）の衝突による人的被 害の割合が増加している. 例えば, 岐阜県と長野県境に位 置する御獄山において, 2014 年 9 月 27 日に突然発生した 水蒸気噴火では, 山頂付近にいた登山客の多くに飛来し た噴石が衝突し，死者だけで 58 名（2021 年 4 月現在）に


守る手段として, 著者らの一部を含むグループが避難場 所となる火山シェルターの安全性に関する実験的検討を

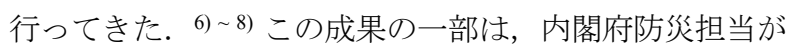
2015 年 12 月に発行した「活火山における退避境等の充実

原稿受理＼cjkstart令和3年4月18日 Received Apr. 18, 2021 C2022 The Society of Materials Science, Japan

正 会 員 防衛大学校 機械工学科 =239-8686 横須賀市走水

Department of Mechanical Engineering, National Defense Academy, Hashirimizu, Yokosuka, 239-8686.

** 防衛大学校 機械工学科 学部生 $=239-8686$ 横須賀市走水

Undergraduate Student, Department of Mechanical Engineering, National Defense Academy, Hashirimizu, Yokosuka, 239-8686.

*** 正 会 員 金沢大学 理工研究域 フロンティア工学系 $\overline{7} 920-1192$ 金沢市角間町

Faculty of Frontier Engineering, Institute of Science and Technology, Kanazawa University, Kakuma, Kanazawa, 920-1192.

**** 正 会員 立命館大学 理工学部 機械工学科 $\bar{T} 525-8577$ 草津市野路東

Department of Mechanical Engineering, School of Science and Engineering, Ritsumeikan University, Nojihigashi, Kusatsu, 525-8577.

***** アジア航測(株) 干215-0004 川崎市麻生区万福寺

Asia Air Survey Co., Ltd., Manpukuji, Asao-ku, Kawasaki, 215-004.

****** (株) 谷沢製作所 $\bar{\top} 104-0041$ 東京都中央区新富

Tanizawa Seisakusho, Ltd., Shintomi, Chuo-ku, Tokyo 104-0041. 
に向けた手引き」9)に記載され，多くの山小屋が補強され ることでシェルターの機能を有すようになった。 しかし, これまでの研究は，避難施設の充実化に焦点を当ててお り，避難施設にたどり着くまでの人を直接守る火山防災 装備については研究が遅れているのが現状である.

人体を守る火山防災装備の代表格が重要部位である頭 部を保護するへルメットである. 内閣府および気象庁が 提示している火山への登山の備えとして，ヘルメットの 着用が噴石対策として推奨されている。10) また, 御获山 では 2014 年の噴火以降, 自治体を中心に登山客にへルメ ット装備を呼びかけている. 11) 火山活動が活発な桜島の 周辺では, 児童・生徒がヘルメットを被って登下校してお

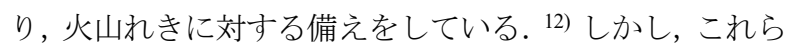
のように，国や自治体がヘルメットの着用を訴えかけて も, 現実問題として, 肝心なへルメットに対する火山れき 等の衝突に対する安全性は評価されていない. すなわち, 火山防災においてヘルメットの着用を推奨しているが, その根拠となる理由は明示されていないのが現状である.

そこで本研究では，火山噴火時に広範囲に多数飛散す る火山れきの衝突現象を評価できる試験装置を開発する. また, 模擬火山れきを用いて, 市販されている登山用へル メットの耐衝撃特性評価を行い, 安全の限界を明らかに する.

\section{2 模擬火山れき}

噴石衝突試験において, 実際に飛散する噴石を使用し た実験は再現性の確保が困難である.そこで，これまでの 火山防災シェルターに関する実験 6) 8) と同様に，噴石の 標準的な密度約 $2400 \mathrm{~kg} / \mathrm{m}^{3}$ とほぼ同程度の密度を持つビ トリファイド砥石を模擬火山れきとして用いた. 火山噴

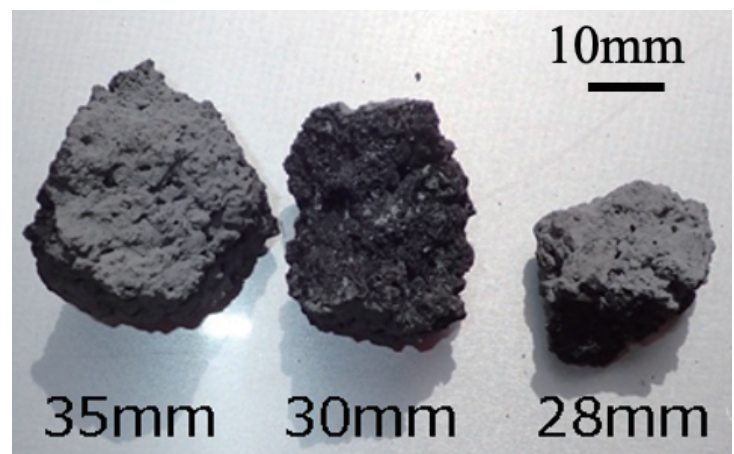

Fig. 1 Lapilli scattered by Aso volcano eruption on October 8, 2016.
火において広範囲に飛散する火山れきは, 直径 $2 \mathrm{~mm}$ 程度 の小さなものから直径 $64 \mathrm{~mm}$ 程度の大きなものがある.

Fig. 1 に示寸直径約 $30 \mathrm{~mm}$ 相当の火山れきは, 2016 年 10 月 8 日の阿蘇山中岳第一火口における噴火で実際に飛散 したものである.これらは噴火口から約 $4.4 \mathrm{~km}$ 離れた網 戸付きの窓ガラスを破壊していることから，火山れきは， 広範囲に飛散しかつ相当の破壊力を持つことがわかる. 本物の火山れきを採取, 加工して衝突試験に使用するこ とは困難なため, 本研究では, 直径約 $30 \mathrm{~mm}$ 相当の火山 れき（約 $35 \mathrm{~g}$ ) を想定し，ビトリファイド砥石を用いて， 同質量となる体積かつ加工が容易な円柱状（直径 $20 \mathrm{~mm}$ ×長さ $45 \mathrm{~mm}$ ）とした。これを発泡ポリスチレン製のサ ボ (発泡倍率 30 倍, 直径 $50 \mathrm{~mm}$, 長さ $50 \mathrm{~mm}$ で穴径が直 径 $20 \mathrm{~mm}$, 深さ $20 \mathrm{~mm}$ ) に挿入し, 後述する衝突試験装 置の発射管へ装填できるようにした. 速度計測のために, 内部にはネオジム磁石（直径 $10 \mathrm{~mm} \times$ 長さ $10 \mathrm{~mm}$ ) を設 置している.

\section{3 登山用ヘルメット}

登山用のヘルメットは, 滑落, 落石等による頭部傷害を 防止するための対策として, 国際山岳連盟（UIAA）によ って定められた安全基準UIAA106 規格 ${ }^{13) や ヨ ー ロ ッ ハ ゚ の ~}$


在する．基準が厳しいUIAA106 規格を見ると，例えば衝 撃吸収特性については, ヘルメットに $5 \mathrm{~kg}$ の半球形スト ライカを $2 \mathrm{~m}$ の高さから落下した際に衝撃荷重 $8 \mathrm{kN}$ 以下 になるように, また, 耐貫通性としてへルメットに $3 \mathrm{~kg}$ の 円錐形ストライカを $1 \mathrm{~m}$ の高さから落下した際にストラ イカが頭部モデルに接触しないように設計することが求

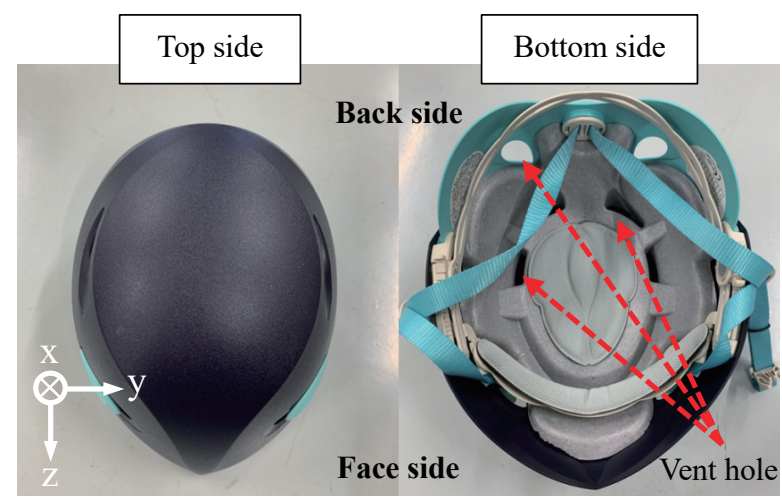

Fig. 2 Top and bottom sides of the helmet used in this study.

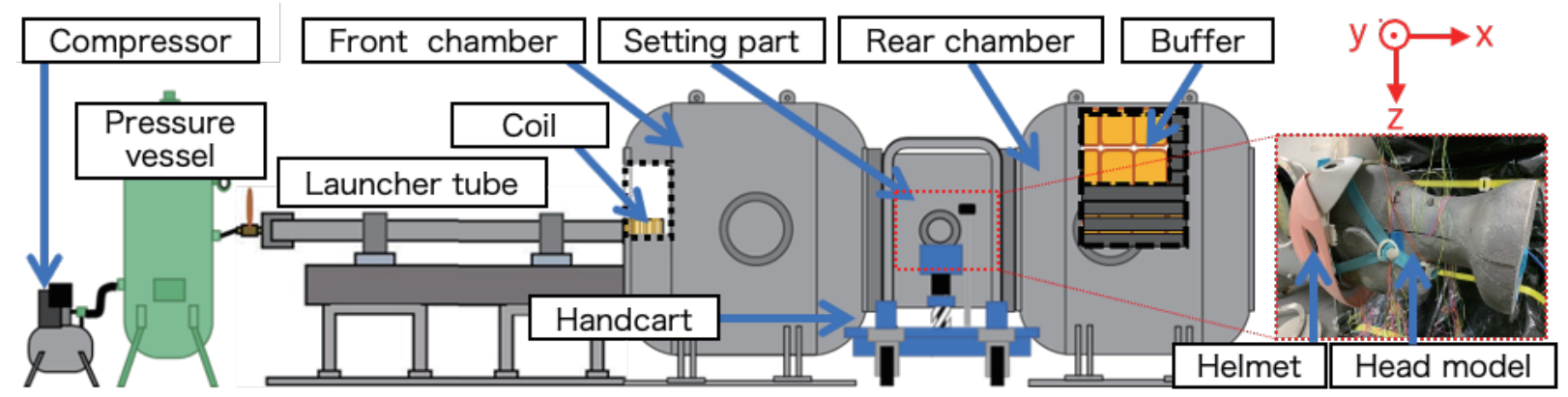

Fig. 3 Schematic diagram of impact test equipment for simulated lapilli. 
められる. 本研究で使用したヘルメットは, 材料および構 造だけでなく, 耐久性や衝撃吸収性, あご紐の強さなどの 観点から，これらの規格に適合している. なお，これらの 規格の值は，産業用保護帽の規格である昭和 50 年労働省 告示第 66 号 ${ }^{15)}$ の飛来・落下用も包括している. しかし, 前述の通り，登山用のヘルメットの耐噴石衝突安全に関 する規格は存在しないため, この值が火山防災用として 利用できるかは，実際の現象に近い衝突実験による検討 が必要である.

そこで，本研究では 2016 年 4 月に販売された谷沢製作 所製の登山用へルメット「ravina FLUQUE」を用いて検討 を行った. 欧米人に比べて頭部の縦幅が短く横幅が長い 日本人の頭部を対象として作られている。ヘルメットの 外観の様子を Fig. 2 に示寸．外側は ABS 樹脂で，内部は 軽量かつ衝撃吸収および緩衝を期待して発泡倍率 20 倍の 発泡ポリスチレン（EPS）を用いている．また，底面側か ら見ると，一般的な産業用へルメットとは異なり登山用 のため, ABS 樹脂と EPS に穴を開けることで通気性が確 保されている.

\section{4 衝突試験}

\section{$4 \cdot 1$ 衝突試験装置}

本研究では, 直径 $50 \mathrm{~mm}$ 以下の飛翔体発射が可能な衝 突試験装置を開発した. 装置の概略を Fig. 3 に示す. 装置 は試験体設置部の前後部にチャンバーを持つデュアルチ ヤンバー(スペース・ダイナミックス研究所製, MCIF-2VPS）を用いた. 衝撃緩衝材をチャンバー内部の側面全体に 設置しており，衝突後の飛散物の二次衝突からチャンバ 一内を守ることで安全な実験が可能である。射出管は内 径 $50 \mathrm{~mm}$, 全長 $2 \mathrm{~m}$ のステンレス合金製のホーニング管 を使用した。 タンクに貯めた圧縮空気を手動バルブで開 放することで，この射出管に装填した飛翔体を射出する. なお, 本研究では, 試験を簡便に行うために, 飛翔体を保 護するサボを分離せずそのまま衝突させている。サボ単 体で $100 \mathrm{~m} / \mathrm{s}$ を超える衝突試験を行ったが, サボは破壊し, 後述する加速度センサでは加速度が測定されなかった。 この際, ヘルメットの表面には損傷がないことを確認し ている.よって, サボのヘルメットへの衝突の影響は軽微 であると判断した.

射出管の出口付近に，コイル（直径約 $60 \mathrm{~mm}, 70$ 巻） を $20 \mathrm{~mm}$ 間隔で 3 本設置した. 飛翔体に取り付けたネオ ジム磁石のコイル通過時に発生する誘導起電力を利用し

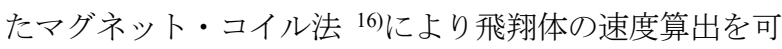
能にした.

\section{$4 \cdot 2$ 人頭モデル}

本研究では，登山用へルメットを装着した人体頭部へ の衝突時に作用する加速度を基にヘルメットの安全性評 価を行う。衝撃負荷を受けた頭部への影響は, 輸送機器等 の交通事故，転倒，転落において，自動車試験用人体ダミ 一（例えば Hybrid-III 50th 等）の頭部を使用することが多 い. しかし, 本研究では, 衝突試験により, ヘルメットを
貫通して，頭部モデルを破壊する恐れがある.

そこで，頭部および頸部から成るアルミニウム合金製 (AC3A : Al-Si 系合金) 人頭モデルを自作した. 発泡高分 子材料でできた頭部を利用して鋳造にて造形し, 内部を 切削加工し空洞を作ることで，頭部 $5.2 \mathrm{~kg}$, 頸部 $3.9 \mathrm{~kg}$ と した.この空洞部の後頭骨内側の位置に 3 軸加速度セン サ (PCB 製，350B50，最大加速度 $\left.\pm 98000 \mathrm{~m} / \mathrm{s}^{2}\right)$ を設置し た. 本研究では, 3 軸加速度センサは, Fig. 3 中に示した $\mathrm{x}$ 軸, $\mathrm{y}$ 軸, $\mathrm{z}$ 軸になるように設置しており, それぞれ正 の方向が解剖学的正位における下方向, 左方向, 前方向と なる. 加速度の計測は，オシロスコープ（横河計測製，

DLM4038）で行った.

\section{$4 \cdot 3$ 試験および評価方法}

本研究では，火口から高所に噴き上げられた火山れき が落下することを想定し， ヘルメットの頭頂部に模擬火 山れきを衝突させる. そこで, 登山用ヘルメットを装着し た頭部モデルを, Fig.3 中に示すように高強度な糸で吊り 下げてデュアルチャンバーの中間部の設置部にした。糸 で吊るすことで，飛翔体衝突時には，3 軸方向にほぼ自由 に動くことが可能である.

模擬火山れきを約 40～ $80 \mathrm{~m} / \mathrm{s}$ で頭部モデルに衝突させ た. 実際の火山れきの飛散速度は, 噴火の規模やその様相 により変化することから決定が難しい. そこで，2014 年 御猋山噴火の状況を想定し, 標高 $3000 \mathrm{~m}$ で水蒸気噴火が 生じた際の終端速度を考える. 火山れきは, 回転しながら 落下寸る直径 $d=30 \mathrm{~mm}$ の球形と仮定し, 重力加速度 $g=9.8$ $\mathrm{m} / \mathrm{s}^{2}$, 標高 $3000 \mathrm{~m}$ における標準大気の密度 $\rho=0.909 \mathrm{~kg} / \mathrm{m}^{3}$, 火山れき密度 $\rho_{\mathrm{s}}=2400 \mathrm{~kg} / \mathrm{m}^{3}$, 抗力係数 $C_{\mathrm{D}}=0.4$ として, 以

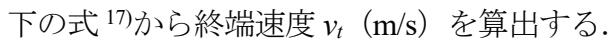

$$
v_{t}=\sqrt{\frac{4 g}{3 C_{\mathrm{D}}}\left(\frac{\rho_{\mathrm{s}}}{\rho}-1\right) d}
$$

算出した結果, 終端速度は約 $51 \mathrm{~m} / \mathrm{s}$ となる. また, 人体 が重篤となる確率が非常に高くなるエネルギーは，古く から $79 \mathrm{~J}$ がよく利用されている。18)このエネルギーを基 準とすると, 衝突速度は約 $67 \mathrm{~m} / \mathrm{s}$ となる. 本研究では, こ れら速度での衝突安全を目安として, 実験結果の考察に 用いる.

また, 衝突時の人頭モデルの 3 軸加速度を計測し, 同時 に登山用ヘルメットの破損状態を確認した. 本研究では, 飛翔体衝突が人体に与える影響を頭部モデルに加わる加 速度から導き出される頭部損傷基準值（Head Injury Criterion: HIC) 19)を用いて評価した. HIC は次式から算出 できる.

$$
\mathrm{HIC}=\left\{\left[\frac{1}{\left(t_{2}-t_{1}\right)} \cdot \int_{t_{1}}^{t_{2}} a_{R}(t) d t\right]^{2.5}\left(t_{2}-t_{1}\right)\right\}_{\max }
$$

ここで, $t_{1}$ と $t_{2}$ は積分時間間隔 $t_{2}-t_{1}$ が $15 \mathrm{~ms}$ を超えない範 囲で HIC が最大となるように選んだ. $a_{R}(\mathrm{G})$ は実験で得 

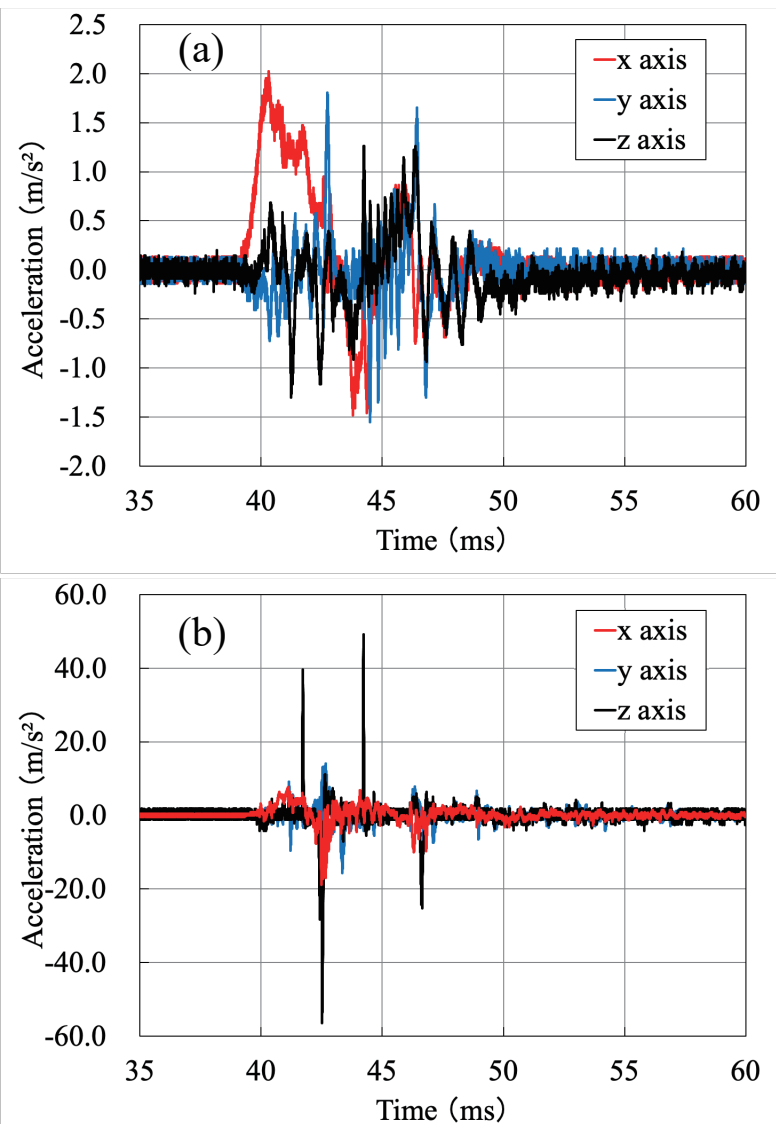

Fig. 4 Relationship between acceleration and time. (a) $44.4 \mathrm{~m} / \mathrm{s}$ : No.1, (b) $74.0 \mathrm{~m} / \mathrm{s}:$ No.14 in Table 1.

られる同時刻の 3 軸方向加速度の合成值であり，以下の 式を用いて算出した.

$a_{R}(t)=\frac{\sqrt{a_{\mathrm{x}}(t)^{2}+a_{\mathrm{y}}(t)^{2}+a_{\mathrm{z}}(t)^{2}}}{9.8}$

ここで，ある時刻における $\mathrm{x}$ 軸， $\mathrm{y}$ 軸， $\mathrm{z}$ 軸方向の加速度 $\left(\mathrm{m} / \mathrm{s}^{2}\right)$ をそれぞれ $\alpha_{\mathrm{x}}(t) ， \alpha_{\mathrm{y}}(t) ， \alpha_{\mathrm{z}}(t)$ とする.

HIC は統計值として人体頭部が重大損傷を受けるとさ れる数值が存在するが，本研究で作製した人頭モデルは 頸部の質量が大幅に加味されるため，本実験では頭部の みより低い加速度で挙動する．よって, HIC は統計值と比 較せず，人体に与える影響の大きさを相対的に評価する 指標として利用する. そこで, 飛翔体衝突によって頭部モ デルを損傷させないように加速度を与える手段として, 木製ハンマーを用いてヘルメット無しの状態に最大限の 人力で頭頂部を打撃した. その結果, HIC は平均 216 を示 した. 本頭部モデルでは，安全率を考慮して， HIC=100を 安全性の目安とする。

本研究では，各実験条件におけるへルメットの安全性 評価結果を 3 通りに分類した. HIC が 100 以下かつへル メットが破壊しない状態を○，HIC が 100 以下であるが ヘルメット表面が破壊している状態を○，ヘルメットの 損傷の有無に関わらず HIC が 100 を超えた場合を×と定 義する.よって, ○と○はへルメット表面の破損の有無の
Table 1 Summary of experimental results. *Measurement error due to oscilloscope overrange.

\begin{tabular}{|c|c|c|c|c|}
\hline No. & $\begin{array}{c}\text { Impact } \\
\text { velocity } \\
(\mathrm{m} / \mathrm{s})\end{array}$ & $\begin{array}{c}\text { Impact } \\
\text { energy } \\
(\mathrm{J})\end{array}$ & HIC & $\begin{array}{c}\text { Safety } \\
\text { evaluation }\end{array}$ \\
\hline 1 & 44.4 & 36.9 & 1.43 & $\bigcirc$ \\
\hline 2 & 47.6 & 42.4 & 0.89 & $\bigcirc$ \\
\hline 3 & 48.2 & 43.4 & 0.85 & $\bigcirc$ \\
\hline 4 & 49.4 & 45.6 & 1.01 & $\bigcirc$ \\
\hline 5 & 49.4 & 45.6 & 4.93 & $\bigcirc$ \\
\hline 6 & 52.6 & 51.7 & 1.34 & $\bigcirc$ \\
\hline 7 & 54.8 & 56.1 & 10.2 & $\bigcirc$ \\
\hline 8 & 57.1 & 61.0 & 1.56 & $\bigcirc$ \\
\hline 9 & 58.8 & 64.6 & 3.88 & $\bigcirc$ \\
\hline 10 & 60.6 & 68.7 & 3.69 & $\bigcirc$ \\
\hline 11 & 60.6 & 68.7 & 10.60 & $\bigcirc$ \\
\hline 12 & 69.0 & 89.0 & 278 & $\times$ \\
\hline 13 & 74.0 & 102.4 & 38.3 & $\bigcirc$ \\
\hline 14 & 74.0 & 102.4 & 229 & $\times$ \\
\hline 15 & 80.0 & 119.6 & 1095 & $\times$ \\
\hline
\end{tabular}

みで，人体への影響は軽微とし，安全と判断する.

実際の衝突現象を可視化するために，前方チャンバー に設置した空からハイスピードカメラ（ナックイメージ テクノロジ一製，HX-3）を用いて斜め方向から模擬火山 れきが登山用へルメットに衝突する様子を撮影した。撮

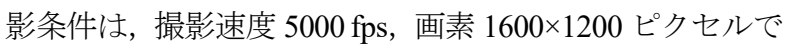
ある。

\section{5 実験結果および考察}

\section{$5 \cdot 13$ 軸加速度の測定結果}

衝突試験から得られた頭部モデルの 3 軸加速度と時間 の代表的な関係として, 低速衝突 $(44.4 \mathrm{~m} / \mathrm{s}$ : 後述の Table 1 における No.1）と高速衝突（74.0 m/s : 後述の Table 1 に おける No.14）の結果を Fig. 4 に示す. 時閒軸はオシロス コープのプリトリガのタイミングに依存した生データと なっている. 頭部モデルの動きを見ているため, ヘルメッ 卜に衝突した直後から加速度が生じているわけでないこ とに注意が必要である。

低速衝突の結果（Fig.4(a)）を見ると，あるタイミング でほぼ同時に 3 軸方向の加速度が検出されることがわか る。飛翔体は $\mathrm{x}$ 軸の正の方向に向かって射出しているた め, $\mathrm{x}$ 軸の加速度ピークが一番大きく持続時間が長い出力 となった. なお, $\mathrm{y}$ 軸および $\mathrm{z}$ 軸については, 頭頂部の衝 突箇所によってその大小が変化する結果を得ている. $\mathrm{x}$ 軸 方向の大きなピーク值の後は, それぞれの方向に高い周 波数の加速度が生じている. 一方，高速衝突（Fig. 4 (b)) では，最初に現れるピークは低速衝突と同様に $\mathrm{x}$ 軸方向 であるが，その值より非常に大きなピークが $\mathrm{z}$ 軸方向で 繰り返し見られた。詳細な観察結果は後述するが，No.14 は飛翔体が衝突部で深く突き刺さっていたことから，飛 


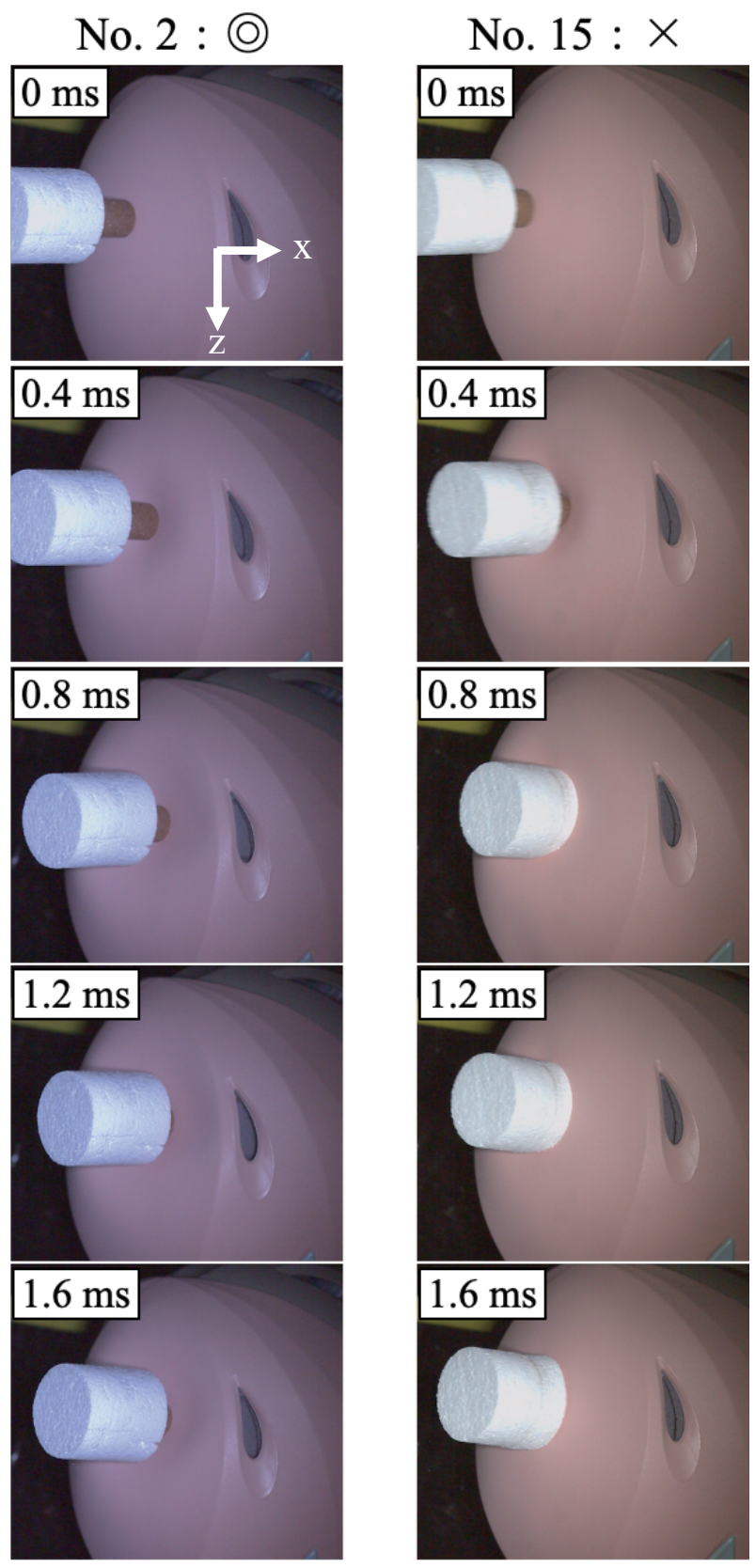

Fig. 5 Image comparison extracted from high-speed camera shooting of No. 2 and No. 15 in Table 1.

翔体の運動エネルギー(衝突エネルギー) が登山用ヘルメ ットを介して頭部モデルに大きな慣性力を与えることで 回転運動が生じ, 大きく摇れたことが原因と考えられる.

\section{$5 \cdot 2$ 登山用ヘルメットの安全評価}

各衝突速度条件における飛翔体の衝突エネルギー, HIC, ヘルメットの安全性評価の判定結果を Table 1 にまとめる. 主に, 約 40〜 $50 \mathrm{~m} / \mathrm{s}$ の衝突速度領域では@, 約 50〜 $60 \mathrm{~m} / \mathrm{s}$ の衝突速度領域では○，これ以上の速度領域ではメとな る傾向が見られた. よって, 終端速度 $(51 \mathrm{~m} / \mathrm{s})$ において は登山用ヘルメットの装着により火山れきに対する衝突 安全性が高まることが実験的に明らかになった。実際に は約 $60 \mathrm{~m} / \mathrm{s}$ まで○の結果となり, 安全裕度を有している. また，試験回数の関係で正確な境界点は断定できいない が， $60.6 \mathrm{~m} / \mathrm{s}$ (No. 11) と $69 \mathrm{~m} / \mathrm{s}$ （No. 12）を境目に HIC が

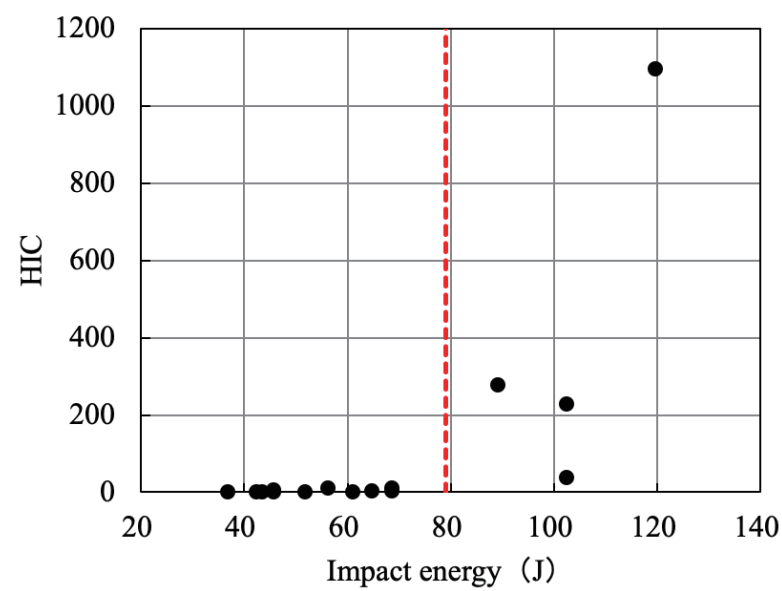

Fig.6 Relationship between HIC value and impact energy. The dashed line in the figure indicates $79 \mathrm{~J}$ as a criterion proposed in Ref. 18).

大きく増加する結果となった.

Fig 5 に@を示した No.2 とメの中で最大の HIC を示し た No.15 のハイスピードカメラ映像の比較を示す. No.2 では，衝突により表面の ABS 樹脂を破壊することなく， 衝突により接触部で大きな変形が生じ，この変形が周り に伝ぱする様子が見られた。抽出した画像のみではわか りにくいが, この変形の後にヘルメット全体が振動して いる様子が観察された. 変形が広範囲に生じることが衝 撃緩衝に寄与していると考えられる. 一方, No. 15 は表面 の $\mathrm{ABS}$ 樹脂が破壊し, 飛翔体が突き刺さった. 衝突直後 からの表面の変形はNo.2 に比べて範囲が狭い. この突き 刺さりにより $\mathrm{x}$ 軸方向に大きな負荷が生じ, 高い HIC を 示したと考えられる.

\section{$5 \cdot 3$ 登山用ヘルメットの破損状態とHICの関係}

Fig. 6 に HIC と衝突エネルギーの関係を示す. 図中の赤 線で示す $79 \mathrm{~J}$ 付近を境にして HIC は衝突エネルギーに対 し指数関数的に上昇している. そこで, 衝突エネルギー79 $\mathrm{J}$ 付近の HIC が高い場合と低い場合のヘルメットの破損 状態を比較し, ヘルメットの破壊様相と HIC の大小の関 連性を探す. なお, ヘルメットの裏面は, EPS の変形およ び破壊の様子を観察するために, Fig. 2 で見られる面ファ スナーで取り付けられている頭部接触保護部材を取り外 した.

衝突エネルギー79 J を境目に HIC が低い場合（No.10） と高い場合（No.12）のヘルメットの破損状態を Fig. 7 に 示す. 表面の $\mathrm{ABS}$ 樹脂は, $\mathrm{HIC}$ の值に関わらず破壊され ており，HIC が高い場合は飛翔体が突き刺さったままの 状態となっている. 董面を見ると, HIC の有無に関わらず, 衝突箇所はへルメット後頭部側であるが, その様子は異 なる. HIC が低い場合，衝突箇所直下の EPS の割れやき 裂とともに後頭部側もき裂が生じており，広範囲に破壊 が生じていることがわかる. 一方, HIC が高い場合は, HIC が低い場合に比べて破壊している面積は増えているが, 同時に割れやき裂は衝突部に限られ，局所的な破壊とな っている. 


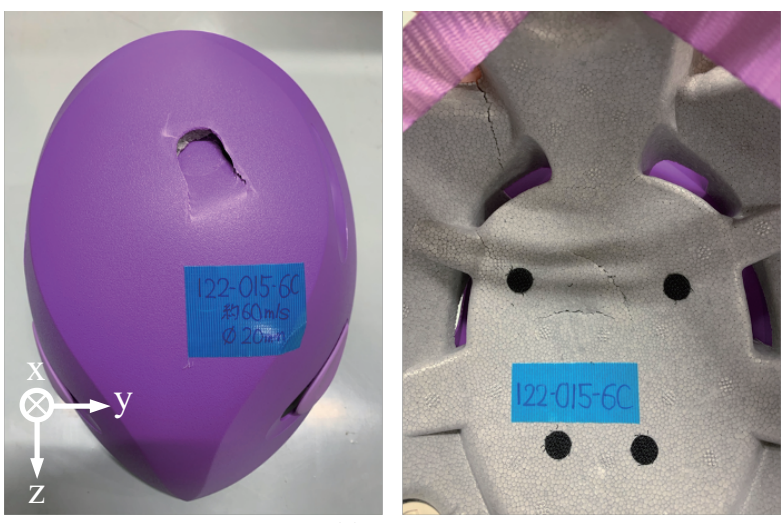

(a) No. 10

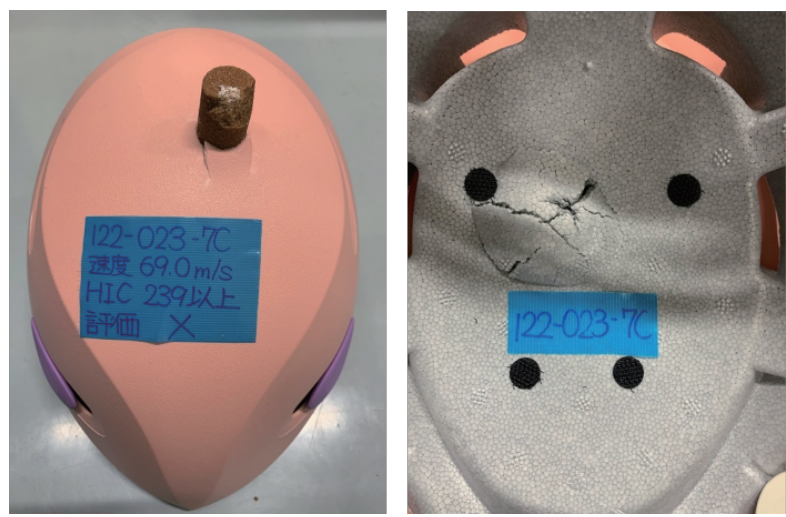

(b) No. 12

Fig. 7 Comparison of damage conditions in helmets when HIC around $79 \mathrm{~J}$ is low (a) and high (b).

次に衝突エネルギーが $79 \mathrm{~J}$ 以上で等しいが HIC が大き く異なった $2 つ （ N o .13$ および 14）を比較する. Fig. 8 に この 2 つのヘルメットの破損状態を示す. 表面は, HIC の 值に関わらず破断が生じ, 飛翔体が突き刺さった. 裏面で は，HIC が低い方は前述の No.10 と同様に衝突箇所がへ ルメット後頭部側であり，EPS の割れやき裂が広範囲に 生じている，一方，HIC が高い場合は，No.12の結果と同 じように割れやき裂は衝突箇所直下に限られ，局所的な 破壊が生じている.

一方，一番大きな HIC を示した No.15 は，表面の ABS 樹脂および内部 EPS を貫通し，頭部モデルの頭頂部に衝 突した痕跡が見られた。 HIC の值に関わらず貫通により 頭部に衝突することは，この速度域ではヘルメット着用 の効果が低いことを示している.

上記の結果より, 使用した登山ヘルメットでは, 衝突箇 所によって内部の EPS の破損状態が変化し，これが HIC の值に影響を及ぼすことが明らかになった．前述の通り， 本研究で使用した登山用ヘルメットは, 滑落, 落石等の対 策や登山用へルメットの規格によって材料や内部構造が 設計されている．特に，衝撃については， $2 \mathrm{~m}$ からの落錘 試験のみで，その速度は約 $6.3 \mathrm{~m} / \mathrm{s}$ と本研究で行なった速 度と比較して低速である.この程度の変形速度では, 変形 伝播速度は変形速度より十分速く，変形領域は広範囲に 分散される。一方，高速衝撃では，衝撃吸収を期待してい た発泡材料の変形が全体に広がる速度よりも衝突速度の

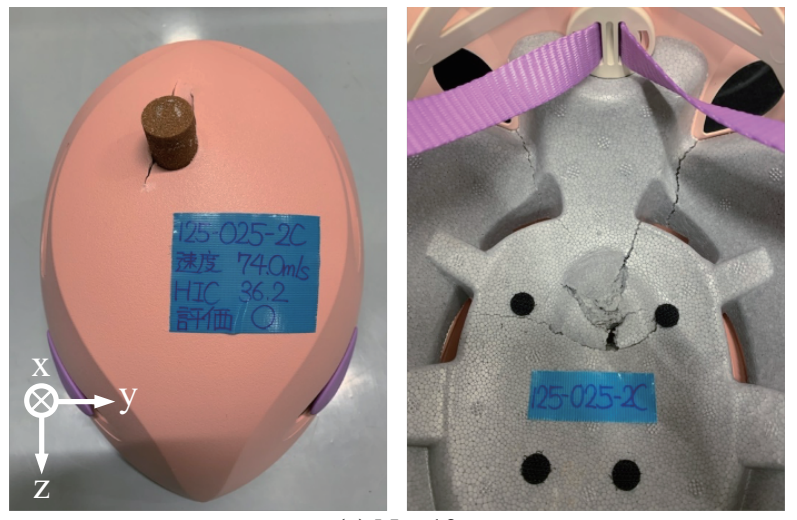

(a) No. 13

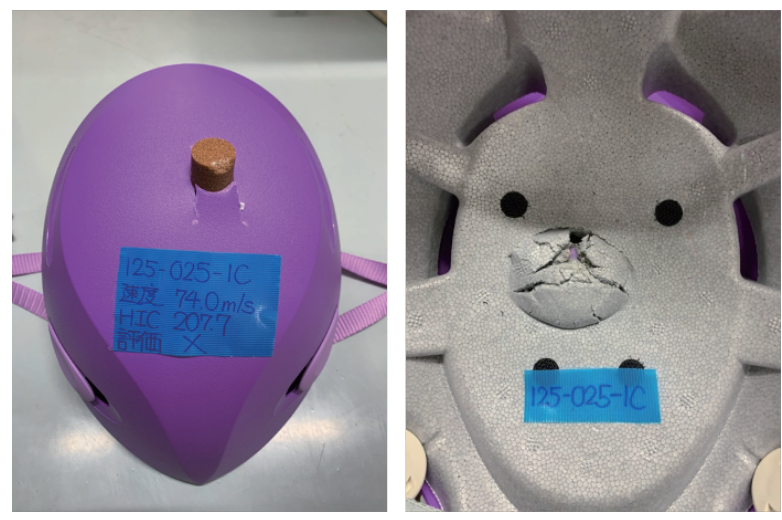

(b) No. 14

Fig. 8 Comparison of damage conditions in helmets when HIC is low (a) and high (b) with the same impact energy higher than 79J.

方が速くなり，変形が分散する前に表面 $\mathrm{ABS}$ 樹脂が局所 変形し，貫通してしまったと考えられる.

よって,これまでの登山用へルメットの設計で, 直径 30 $\mathrm{mm}$ までの火山れきに対しては, 十分な耐衝撃安全設計が なされていると考えられる。一方で, 実験結果より, 内部 保護用の発泡材料の変形と破壊を局所から分散させるこ とが HIC 低減に大きく寄与する可能性がわかった。 衝撃 吸収構造を改善することで，より高い衝突エネルギーに 耐えられる登山用ヘルメットの開発が期待できる.

\section{6 結 言}

本研究では，直径50 mm以下の飛翔体を発射できる衝突 試験装置と自作の人頭モデルを用いて，市販されている登 山用ヘルメットの衝突安全性評価を行い, 以下のことがわ かった.

(1) 本研究で使用したヘルメットの頭頂部に直径 $30 \mathrm{~mm}$ 相当模擬火山れきを衝突させたところ, 衝突速度約 $60 \mathrm{~m} / \mathrm{s}$ までは低い HIC を示し, 安全性を担保するこ とがわかった。

(2) 模擬火山れきがへルメットの表面を貫通しても HIC の值に差が生じた. 内部の保護用発泡材料が広範囲 に破壊すると低い值を示し，局所的に破壊すると高 いHIC を示した. よって, 人体への影響を低減させ るためには, 内部保護材料の破壊プロセスの影響が 大きく現れることが示唆された.

今後，火山れきの最大直径である $64 \mathrm{~mm}$ を基準とし て，さらに衝突安全が向上した登山用ヘルメットの開発 
が課題である。

3 軸加速度センサを用いた測定について，防衛大学校 機械工学科 藤原浩幸 氏から多くのご助言をいただいた。 また, デュアルチャンバーの組み立てには, 防衛大学校理 工学研究科機械工学専攻 酒井大誠 氏にご協力いただい た。ここに記して謝意を表する.

\section{参 考 文 献}

1) Japan Meteorological Agency, https://www.data.jma.go.jp/svd/vois/data/tokyo/STOCK/ kaisetsu/volsaigai/saigai.html (accessed on 17 April 2021).

2) G. Wilson, T.M. Wilson, N.I. Deligne and J.W. Cole, "Volcanic hazard impacts to critical infrastructure: A review", Journal of Volcanology and Geothermal Research, Vol. 286 pp.148-182 (2014).

3) T. Oikawa, K. Yamaoka, M. Yoshimoto, S. Nakada, Y. Takeshita, F. Maeno, Y. Ishizuka, J. Komori and S. Nakano, "The 2014 eruption of Ontake volcano, central Japan", Bulletin of the Volcanological Society of Japan, Vol. 60, pp.411-415 (2015).

4) T. Kaneko, F. Maeno and S. Nakada, "2014 Mount Ontake eruption: characteristics of the phreatic eruption as inferred from aerial observations", Earth, Planets and Space, Vol. 68, 72 (2016).

5) T. Oikawa, M.Yoshimoto, S. Nakada, F. Maeno, J. Komori, T. Shimano, Y. Takeshita, Y. Ishizuka and Y. Ishimin, "Reconstruction of the 2014 eruption sequence of Ontake Volcano from recorded images and interviews", Earth, Planets and Space, Vol. 68, 79 (2016).

6) H. Yamada, K. Tateyama, H. Sasaki, S. Naruke, H. Kisimoto and M. Yoshimoto, "Impact resistance to ballistic ejecta of wooden buildings and a simple reinforcement method using aramid fabric", Journal of Volcanology and Geothermal Research, Vol. 359, pp.3746 (2018).

7) H. Yamada, K. Tateyama, R. Honda, M. Yoshimoto and T. Fujii, "Simple structural reinforcement of roof of wooden buildings subjected to ballistic ejecta impact", Bulletin of the Volcanological Society of Japan, Vol. 64, pp.243-251 (2019).
8) K. Tateyama, S. Naruke, H. Sasaki, T. Fukui and H. Yamada, "Impact resistance evaluation of tatami to improve the safety of mountain huts", Bulletin of the Volcanological Society of Japan, Vol. 65, pp.41-51 (2020).

9) Disaster Management, Cabinet Office, http://www.bousai.go.jp/kazan/shiryo/pdf/201512_hinan tebiki3.pdf (accessed on 17 April 2021).

10) Disaster Management, Cabinet Office, http://www.bousai.go.jp/kazan/kazan_sonae/index.html (accessed on 17 April 2021).

11) Kiso Town, Nagano Prefecture, https://www.townkiso.com/bousai/bousai/100206/100208/ (accessed on 17 April 2021).

12) Kagoshima City, Kagoshima Prefecture, https://www.city.kagoshima.lg.jp/kikikanri/kurashi/bos ai/bosai/sakurajima/documents/bousaibook.pdf (accessed on 17 April 2021).

13) UIAA Safety Standards, UIAA 106 (Helmets).

14) European Standards, EN 12492: 2012 (Helmets for mountaineers).

15) Ministry of Health, Labor and Welfare, https://www.mhlw.go.jp/web/t_doc?dataId=74066000\&d ataType $=0 \&$ page $\mathrm{No}=1$ (accessed on 17 April 2021).

16) K. Watanabe, "Phenomena induced by high-speed impact to particulate materials", Journal of the Society of Materials Science, Japan, Vol. 66, pp.288-291 (2017).

17) R. Gunn and G.D. Kinzer, "The terminal velocity of fall for water droplets in stagnant air", Journal of Atmospheric Sciences, Vol. 6, pp.243-248 (1949).

18) M.V.D. Voort and E.L. Baker, "Ballistics trajectory and impact analysis for fragment impact testing insensitive munitions and hazard classification project criteria". AIP Conference Proceedings, Vol. 1979, 120007 (2018).

19) R. Eppinger, E. Sun, F. Bandak, M. Haffner, N. Khaewpong, M. Maltese, S. Kuppa, T. Nguyen, E. Takhounts, R. Tannous, A. Zhang and R. Saul, "Development of improved injury criteria for the assessment of advanced automotive restraint systems II", Chap. 2 Head Injury Criteria (1999) National Highway Traffic Safety Administration. 